\title{
Socio-economic Impacts—Coastal Protection
}

\author{
Hanz D. Niemeyer, Gé Beaufort, Roberto Mayerle, Jaak Monbaliu, \\ lan Townend, Holger Toxvig Madsen, Huib de Vriend \\ and Andreas Wurpts
}

\begin{abstract}
All North Sea countries are confronted by climate change impacts such as accelerated sea-level rise, increasing storm intensities resulting in as well higher set-up of storm surges as growing wave energy and a follow-up of morphological changes. Thus it is necessary to question the effectiveness of existing coastal protection strategies and to examine alternative strategies for coastal protection under a range of scenarios considered possible. Scenarios of accelerating sea-level rise leading to changes in sea level of up to $1 \mathrm{~m}$ or more by 2100 and higher set-up of storm surges with increasing wave energy have been used for planning purposes. Adaptation strategies for future coastal protection have been established in all North Sea countries with vulnerable coasts, observing two propositions: (1) structures are economic to construct in the short term and their dimensions easily adapted in the future to ensure flexibility in responding to the as yet undeterminable climate change impacts and (2) implementation of soft measures being temporarily effective and preventing counteraction to natural trends. The coastal protection strategies differ widely from country to country, not only in respect of distinct geographical boundary conditions but also in terms of the length of the planning period and the amount of regulations. Their further development is indispensable and emphasis must more and more be laid on strategies considering the effects of long-term development of coastal processes for future coastal protection. Filling gaps in knowledge is essential for developing sustainable adaptation strategies.
\end{abstract}

H.D. Niemeyer $(\bowtie)$

Independent Consultant, ret., Coastal Research Station, Norderney, Germany

e-mail: hanz.niemeyer@yahoo.com

G. Beaufort

Hydr. Engineering Cons., De Meern, The Netherlands

e-mail: g.a.beaufort@gmail.com

R. Mayerle

Research and Technology Centre Westcoast, Kiel University,

Kiel, Germany

e-mail: rmayerle@ corelab.uni-kiel.de

J. Monbaliu

Department of Civil Engineering, KU Leuven, Leuven, Belgium

e-mail: jaak.monbaliu@kuleuven.be

I. Townend

Ocean and Earth Sciences, University of Southampton,

Winchester, UK

e-mail: I.Townend@soton.ac.uk
H. Toxvig Madsen

Danish Coastal Authority, Lemvig, Denmark

e-mail: holger.toxvig@kyst.dk

H. de Vriend

Independent Consultant, Oegstgeest, The Netherlands

e-mail: hjdevriend@planet.nl

A. Wurpts

Coastal Research Station, Norderney, Germany

e-mail: andreas.wurpts@nlwkn-ny.niedersachsen.de 


\subsection{Introduction}

Climate change will create stronger challenges for coastal protection than experienced in the past. Loads on protection structures are increasing and increased flood risk in the majority of coastal areas has coincided with ongoing growth in population and investment. Since the implementation of measures in coastal protection needs a forerun of decades, the determination of boundary conditions for their design requires an appropriate and sufficiently safe margin for foreseeable developments in the future. This is presently best practice in coastal engineering but becomes more difficult and uncertain the further forward in time considered since there are no reliable forecasts for future climate change impacts, only wide-ranging scenarios. Therefore adaptation strategies for coastal protection must aim to be both economic to construct in the short term and designed such that they can be easily adapted in the future, allowing adequate flexibility in order to respond to the as yet insufficiently determinable effects of future climate change impacts. To meet these requirements, current understanding of climate change effects on coastal protection measures must be used to examine alternative strategies for future coastal protection under a wide range of scenarios for climate change impacts regarded as possible.

\subsubsection{Boundary Conditions of Coastal Protection}

The aims of coastal protection are first the safety of the hinterland against flooding due to storm surges and second to limit coastal retreat. An essential basis for achieving these objectives is sound knowledge of the governing boundary conditions, such as local hydrodynamic loads or morphological processes. Acceleration of sea-level rise (SLR) due to changing global climate will be a threat in all coastal areas. This threat will be compounded by a number of secondary effects of climate change that will increase loads on coastal protection structures or on dunes and cliffs providing shelter for the hinterland against flooding.

Climate change will also lead to increasing storm intensities which will-particularly in the shallower parts of the North Sea - cause higher set-ups of storm surges (EEA 2012; Woth et al. 2006; Weisse et al. 2012). As a result, water depths at the coastlines will increase for design conditions; the shallower the local coastal waters the greater the increase. Since in areas like the Wadden Sea coasts in the southern North Sea, wave heights and periods on tidal flats are strongly depth-controlled (Niemeyer 1983; Niemeyer and Kaiser 2001), any increase in local water depth would be accompanied by correspondingly higher wave loads on coastal structures or on dunes and cliffs (Niemeyer 2010).

Accelerated SLR will also be accompanied by morphodynamic responses in sedimentary coastal areas which may be unfavourable to coastal protection. For instance, adaption of tidal flat levels may no longer keep pace with SLR, and if rates exceed a certain threshold then tidal flats might even disappear (Müller et al. 2007). Water depth in front of coastal structures would then increase and result in the propagation of higher and longer waves during storm surges and thus stronger wave loads. Adaption of tidal flats to SLR is governed by the hydrodynamics of ordinary tides. In contrast, the vertical growth of saltmarshes depends on hydrodynamics during meteorologically enhanced tides and in particular on storm surges (Townend et al. 2011). In addition to this significant disparity in governing boundary conditions there are indications that salt marshes also have a limited capability to grow with sea level: above a certain threshold in the rate of SLR they will no longer keep pace. The threshold for SLR to limit the vertical growth of saltmarshes will be slightly raised, however, by an increase in the frequency of storm surges (Schuerch et al. 2013).

The response of coastal morphology to accelerated SLR is much more pronounced on wave-exposed sandy coasts and barrier islands than, for example, in front of coastlines on estuaries or tidal basins with tidal flats and salt marshes; areas with a high share of cohesive sediments. Adaption of the shoreface to erosion induced by SLR according to the BRUUN-Rule and its steepening will take place simultaneously (Bruun 1962; Stive and de Vriend 1995). Since shoreface processes affect conditions at adjacent beaches (Mulder and de Vos 1989), erosion and coastal retreat will also occur. At interrupted coasts with estuaries or tidal inlets and basins, SLR will increase basin volume and drive an increasing demand for external sediment supply to enable adaptation towards the moving target of morphodynamic equilibrium (Ranasinghe et al. 2012).

The result is erosion of coastal stretches in the vicinity of the tidal inlets, leading to stronger coastal retreat than would occur through shoreface adaption to SLR alone (Ranasinghe et al. 2012). The volume of ebb-deltas will also decline as they will act as the initial source for meeting the increased sediment demand of the basins (Stive and Eysink 1989). Since the sheltering effects of ebb-deltas depend on their sediment volume (Kaiser and Niemeyer 1999), wave penetration into the basin and onto adjacent beaches will be less restricted causing higher loads on structures, dunes and cliffs and increasing erosion of beaches and dunes and, although to a lesser extent, tidal flats and salt marshes. The impact of all such processes will increase, the more SLR is accompanied by an increase in tidal range. 


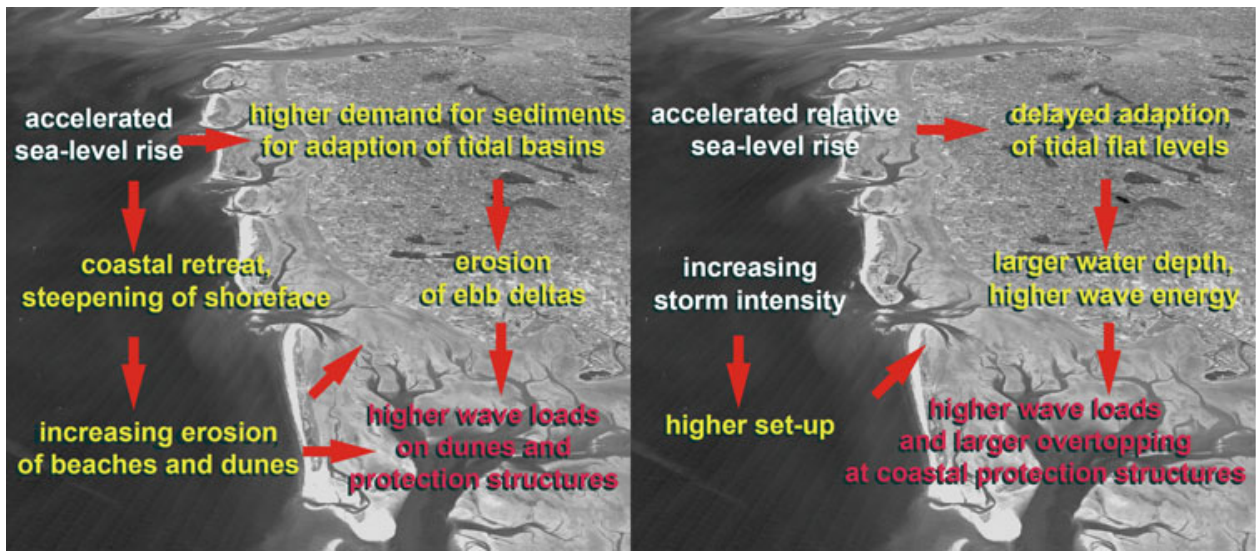

Fig. 18.1 Combined effects of climate change on a North Sea coast: morphodynamics and hydrodynamic loads at a sandy coast (barrier islands) (left) and on hydrodynamic loads on coastal structures at a lowland coast along an estuary and tidal basins with cohesive sediments (right) (Niemeyer 2015); background image from the Common Wadden Sea Secretariat (www.waddensea-secretariat.org)
These secondary effects of climate change are superimposed on each other, and may even invoke a feedback (Fig. 18.1) which further complicates the prediction of future change (Niemeyer 2015). It will be a major challenge for coastal researchers to develop and apply suitable morphodynamic models that can encompass a sufficiently wide range of scenarios for future climate change effects. Such models are needed to meet the knowledge base required for more detailed planning and development of adaptation measures for coastal protection. This is particularly the case for wave-exposed sandy coasts and barrier islands, where the secondary effects of accelerated SLR on morphology are expected to be stronger, faster and more diverse than those anticipated in front of coastlines with a high degree of cohesive sediments, where morphodynamic adaption is more predictable (Niemeyer 2015).

\subsubsection{Coastal Protection Strategies in Response to Climate Change Impacts}

Global warming and the resulting acceleration in SLR necessitates a thorough re-evaluation of coastal protection strategies in many parts of the world. This includes the North Sea coasts of Europe, where coastal protection has a history of more than 1000 years. For most of the North Sea coasts, maintaining a protection line through dykes, solid structures or dunes and cliffs was historically the result of human activity. The potential for faster SLR through global warming has alerted coastal managers to question whether this strategy of keeping the line will still be appropriate, or whether alternative strategies should be considered.

The Intergovernmental Panel on Climate Change (IPCC) Coastal Zone Management Subgroup identified alternative adaptation strategies for SLR: retreat, accommodation and protection (IPCC 1990), following an earlier Dutch evaluation, which also included the additional strategy of moving the defence line seaward (Rijkswaterstaat 1989). All four strategies are manifested in historical practice (Niemeyer 2005, 2010). The strategy 'protection' has since been further differentiated by distinguishing between traditional line protection and alternative protection schemes such as setback or realignment and combined protection (ComCoast 2007). Although moving the defence line seaward is only suitable in very specific situations, and may not always be ethically and politically acceptable, the other strategies are regarded as options for adapting coastal protection in response to possible future climate change effects. Recent investigations have shown that simple conceptual evaluations by graphical schemalizations and purely qualitative discussion such as carried out by ComCoast (2007), are unreliable and sometimes even misleading since important boundary conditions such as hydrodynamic loads, topographic features, existing protection structures and necessary resources are ignored or misjudged. Therefore it is essential to evaluate strategies by applying scenarios for design conditions in real-world environments (Niemeyer et al. 2011a, b, 2014).

The same comments also apply to conclusions drawn by Temmerman et al. (2013) concerning the effectiveness of protection strategies that improve the ecological value of coastal and estuarine areas by a set-back of the existing protection line, since the emphasized equivalence of safety against flooding of the hinterland achieved by the protection strategy applied beforehand is only an assumption. Model tests for proving that assumption are to be carried out in the future thus allowing reliable judgements (STW 2013). The expectation of a reduction in hydrodynamic loads on structures by a set-back strategy (Temmerman et al. 2013) contradicts results being achieved for the evaluation of 
alternative coastal protection strategies by mathematical modelling for design conditions in similar environments (Niemeyer et al. 2011a, b, 2014). Nevertheless, potential improvements in ecological quality by applying alternative strategies should be balanced against the higher capital costs for coastal protection in respect of societal demands.

Although evaluations of protection strategies for coasts with a significant fraction of cohesive sediments yield reliable results, this is not the case for wave-exposed sandy coasts and barrier islands with higher dynamics (Fig. 18.1). The impacts of climate change on coastal processes may require a higher level of adaptation there than at other locations. Taking into account the enormous additional effort this will require, adaptation strategies for wave-exposed sandy coasts and barrier islands will need to accommodate stronger and more variable coastal processes due to future climate change impacts than at present. Such an approach could then serve as a blueprint for the development of flexible coastal protection schemes that are sufficiently adapted to future climate change impacts in order to prevent any incompatibility with future developing trends driven by nature. Such schemes are likely to prove more favourable than some of the traditional coastal protection measures.

\subsection{Adaptive Planning and Regulation}

Adaptation strategies for future coastal protection have been established in all North Sea countries with vulnerable coasts. These differ widely from country to country, especially in terms of the length of planning period and amount of regulation.

\subsubsection{Belgium}

The Flemish Government approved a Master Plan Coastal Safety (Afdeling Kust 2011) in June 2011 comprising calculations and safety assessments for the periods 2000-2050 and 2050-2100. A vision for further development of the Flemish coastal zone is on its way aiming at the integration of safety, natural values, attractiveness, sustainability and economic development including navigation and sustainable energy. This concept is referred to as Vlaamse Baaien or Flanders Bays 2100 (Vlaamse Baaien 2015a, b) and includes conceptual plans for responding to climate change effects beyond 2050. This idea was initiated by a concept study launched by a private consortium of different consultant and construction companies under the name Flanders Bays 2100 (Vlaamse Baaien 2015a). Execution of the Master Plan Coastal Safety, however, is a pre-condition that must be met before implanting the 'Flanders Bays' concept (Vlaamse Baaien 2015a). It is expected that the safety levels incorporating the projected SLR until 2050 will require maintenance nourishments thereafter. For the Belgian part of the Western Scheldt estuary the Sigma Plan was established after the floods of 1976 and was revised in 2005 to include projected SLR until 2050. New understanding of coastal management, which balances safety and environmental protection and also shipping where it plays a key role, have resulted in a vision of multifunctional and sustainable use of the Western Scheldt estuary (Sigmaplan 2016).

\subsubsection{Denmark}

The Danish Government announced its strategy for adaptation to a changing climate in 2008 (Danish Government 2008). The report provides an overview of the challenges arising from future climate change in terms of 11 sectors, one of which is the coastal zone. The adaptation strategy for coastal protection was developed by the Danish Coastal Authority (2012). The aim is to provide coastal communities with a regionally differentiated basis for adaptation to 2050, and then to 2100. Every five years the Coastal Authority undertakes a safety assessment of the central part of the Danish North Sea as a basis for coastal protection planning as well as financial planning. There is no fixed schedule for safety assessments in the Danish Wadden Sea: two have been undertaken since 1999. In all other parts of the Danish coasts the land owners are themselves responsible for protection.

\subsubsection{Germany}

For the German North Sea coast, adaptation strategies in the four federal states are regulated differently. In the Free and Hanseatic City of Bremen a sector plan was established by the ministry (SUBV 2012). The building programme matching the safety levels established in 2007 includes a heightened precaution measure for climate change effects and will be finished in 2025. For the Free and Hanseatic City of Hamburg the parliament accepted a proposal made by the state government which is a guideline for planning until 2050 (Senat FFH 2012). A safety assessment will be undertaken every ten years. In Schleswig-Holstein, design boundary conditions were revised with respect to SLR expected by 2050 and 2100 in an update to the Coastal Protection Masterplan (MELUR 2013); safety assessments are planned every ten years. In 2008, the state government of Lower Saxony established a government commission of management experts, scientists and stakeholders to develop an adaptation strategy for climate change effects including coastal protection, supported by expert groups on specific themes. A well-funded research programme was initiated in 
order to provide the commission with basic information on key issues like coastal protection. A report on the adaptation strategy was delivered in 2012 (MU 2012) and its recommendations for initial actions were approved by the state government in 2013: the optimal strategy for coastal protection at the mainland coast is by keeping the protection line; precautionary observations and investigation programmes are required to address identified knowledge gaps and so enable future substantiation of adaptation measures; and the need to continue the safety assessment programme with a ten-year cycle. Investigations of clay quality in the cover layer of existing dykes as a basis for introduction of increasing overtopping tolerance in future design procedures to balance - at least partly_-higher hydrodynamic loads are a major component of this research programme. Of even greater importance is the identification and quantification of morphological effects due to climate change impacts in the dynamic East Frisian barrier islands region to provide the essential basic knowledge for developing a resilient adaptation strategy for the future protection of the area against flooding and effects of structural erosion. An independent commission shall be appointed to provide recommendations on implementing this programme.

\subsubsection{Netherlands}

In the Netherlands, consideration of climate change effects started earlier than in most other countries (Rijkswaterstaat 1989, 1990). In 2001, a safety assessment procedure was laid down in the Water Act, requiring an assessment every five years, later increased to six. The need for more advanced adaptation to climate change led to the establishment of the second Deltacommissie (2008). Starting from scenarios for SLR and river discharge, this committee produced recommendations which included, among others, the establishment of a Delta Program led by a Delta Commissioner at ministerial level, to recommend how to implement a risk-based flood safety approach and how to establish an effective organisation and legal framework. The Delta Commissie's recommendations were approved by parliament in a Delta Act. A budget of EUR 1 billion per year was initially foreseen for planning and implementing climate adaptation measures, but this has now been revised to EUR 9 billion for the period 2013 to 2028. Adaptation to newly defined safety levels aimed at 2050 is intended to be ready by 2028 . The process is accompanied by an annual National Delta Congress. The Delta Program on several strategic decisions regarding future flood safety and freshwater provision is now finished. The new safety norms are currently being laid down in the new Water Act, and are expected to come into effect as of 2017. Future safety assessments will be undertaken every twelve years (Rijkswaterstaat 2015b).

\subsubsection{United Kingdom}

The Climate Change Act 2008 provides a legally binding and long-term framework to cut carbon emissions in the United Kingdom, but also makes provision for an assessment of the risks of climate change for the United Kingdom to be undertaken on a five-year cycle. The first of these is the 2012 Climate Change Risk Assessment (CCRA) (DEFRA 2012). This was based on climate projections by Lowe et al. (2009) and included an assessment of the economic implications of climate change for different sectors and the potential costs and benefits of different adaptation responses. Building on the outputs of the CCRA, the government and the Devolved Administrations (Northern Ireland, Scotland, and Wales) are developing adaptation programmes that will set out Government objectives for adaptation to climate change as well as proposals and policies to deliver these objectives. The programmes will be subject to regular assessment by the Committee on Climate Change to determine progress towards implementation.

\subsection{Safety Margins for Climate Change Effects}

\subsubsection{Sea-Level Rise Scenarios and Safety Levels}

The safety levels of hydrodynamic loads are the criteria used for dimensioning coastal protection structures to ensure their effectiveness in protecting against flooding due to storm surges. Superimposed safety margins ensure that the structures remain effective against flooding over the course of their anticipated lifespan; safety margins for SLR have been in use since the 1950s and are superimposed on the safety levels for hydrodynamic loads on the structures. The safety margins associated with accelerated SLR and other potential climate change effects are considered in distinct rates in the countries along the North Sea coasts. But ultimately, the safety of the protected areas depends on the aggregated safety margins and safety levels; the latter still the more relevant in respect of the order of magnitude. A comparison of safety levels between countries makes little sense. On the one hand, some countries have introduced distinct safety levels on regional scales, while on the other a comparison of exceedance probabilities is sometimes misleading. If distinct extreme value distributions are used to evaluate design parameters, the same exceedance probability might deliver distinctive results; with the larger the difference the lower the probability of occurrence. Moreover methodological differences like choice of used values or data fitting, and length of time series prevent a credible comparison: benchmarking by exceedance probabilities or return periods is only reasonable 


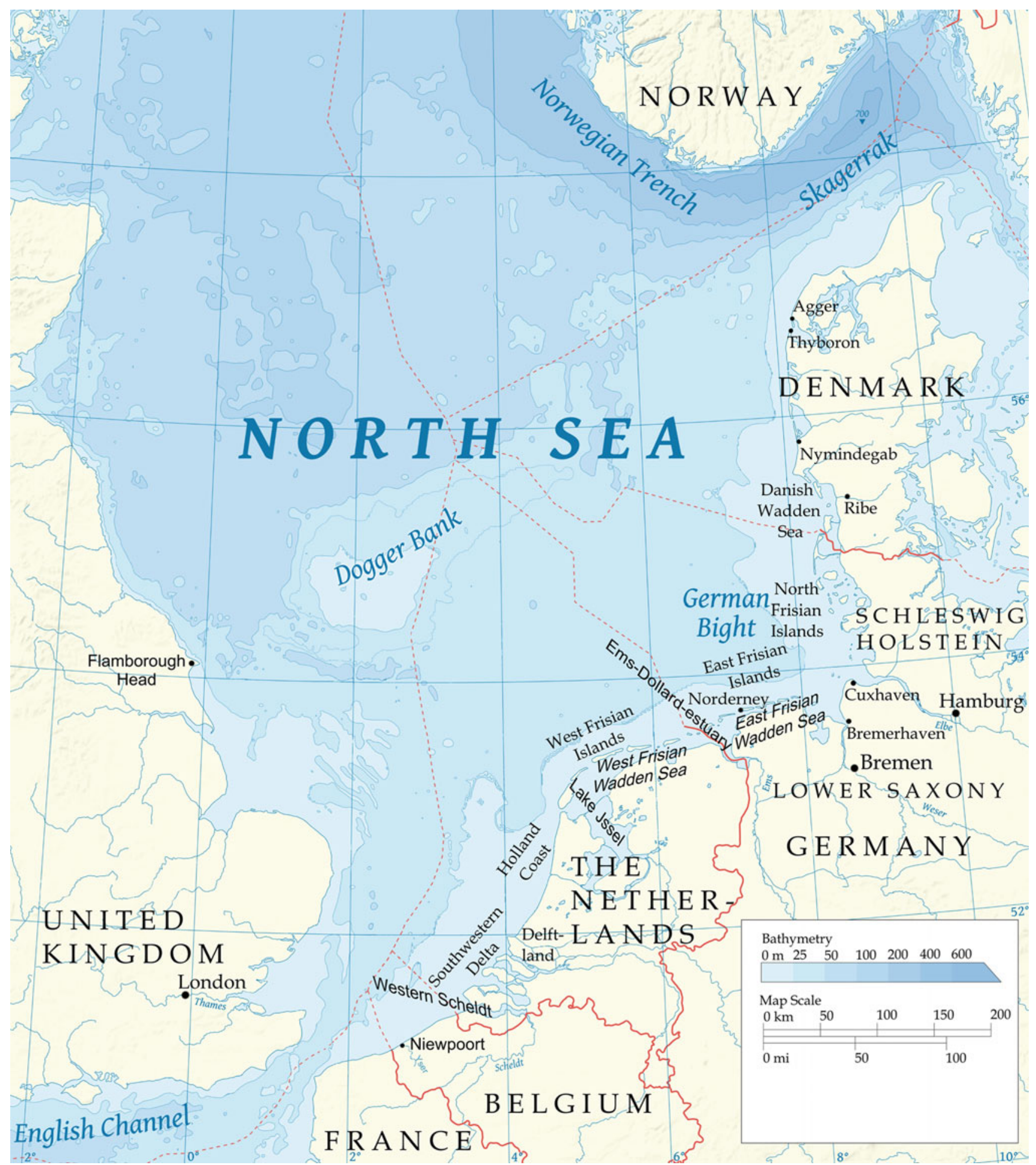

Fig. 18.2 North Sea Basin and surrounding countries (base map: http://de.wikipedia.org/wiki/Datei:North_Sea_map-en.png) 
and provides reliable results if the methodological basis for their evaluation is compatible. Therefore the following review of current safety margins for SLR and other hydrodynamic effects due to climate change includes only a brief description of safety levels. All locations mentioned in the following texts are shown in Fig. 18.2.

\subsubsection{Denmark}

A SLR of $0.1-0.5 \mathrm{~m}$ by 2050 and $0.2-1.4 \mathrm{~m}$ by 2100 is assumed in Denmark. This is partly compensated for by a land rise of $0-0.1 \mathrm{~m}$ by 2050 and $0-0.2 \mathrm{~m}$ by 2100 , leading to a relative SLR of $0-0.5 \mathrm{~m}$ by 2050 and $0-1.4 \mathrm{~m}$ by 2100 . An increase in the set-up of severe storm surges of $0-0.1 \mathrm{~m}$ by 2050 and $0-0.3 \mathrm{~m}$ by 2100 is also assumed due to higher wind velocities resulting also in higher and longer waves. Peak storm surge levels may increase by up to $0.6 \mathrm{~m}$ by 2050 and up to $1.7 \mathrm{~m}$ by 2100 due to the combined effect of SLR and increasing surge set-up. Information on the changing wave climate is provided by comparing actual conditions with scenarios for the period 2071-2100. For dykes on the Wadden Sea coast, cost estimates for adaptation have been carried out. For a recently strengthened $13-\mathrm{km}$ stretch of the dyke line south of Ribe a safety margin of $40 \mathrm{~cm}$ has been considered. The safety level in Denmark is defined for sandy coasts by conditions with a yearly exceedance probability of $10^{-3}$ for the city of Thyboron and $10^{-2}$ for the coastal stretch between Agger and Nymindegab. The width of dunes required to meet that safety level was determined empirically from historical data on dune erosion. Safety levels for the dykes at the Wadden Sea coast of Denmark range between $2 \times 10^{-2}$ and $5 \times 10^{-3}$, depending on population density in the protected area. Design is aimed to achieve these safety levels until 2100, and takes into account projections for SLR, increased set-up of storm surges and changes in wave climate. The level of acceptable overtopping tolerance for dykes is $10 \%$, which is equivalent to approximately $10\left[1 \times\left(\mathrm{m} \mathrm{s}^{-1}\right]\right.$ for the boundary conditions at the Danish Wadden Sea coast. The other parts of the Danish North Sea coast have no flood risk.

\subsubsection{United Kingdom}

Safety levels in the United Kingdom depend on the degree of development of the protected areas. For London and the developed parts of the Thames estuary a yearly exceedance probability of $10^{-3}$ is applied, whereas the corresponding safety level for all other urban areas along the North Sea coast is a yearly exceedance probability of $5 \times 10^{-3}$. For the other parts, lower safety levels are applied in respect of local circumstances. Since 1999, a SLR of $40 \mathrm{~cm}$ is assumed for the North Sea coast north of Flamborough Head for the design of structures with a lifespan of 100 years, and a SLR of $60 \mathrm{~cm}$ for the North Sea coast south of Flamborough
Head. The flood risk management plan for the Thames estuary takes the following safety margins for SLR into consideration (Environment Agency 2013):

- $4 \mathrm{~mm} \mathrm{year}^{-1}$ to 2025

- $8.5 \mathrm{~mm}$ year $^{-1}$ for $2026-2055$

- $12 \mathrm{~mm} \mathrm{year}^{-1}$ for 2056-2085

- $15 \mathrm{~mm} \mathrm{year}^{-1}$ for 2086-2115.

National guidance issued in 2011 advises using the UK Climate Projection 09 (DEFRA 2011) for relative SLR based on the medium-emissions 95th percentile projection for the project location. Upper-end (95th percentile) estimates are as follows:

- $4 \mathrm{~mm} \mathrm{year}^{-1}$ to 2025

- $7 \mathrm{~mm} \mathrm{year}^{-1}$ for 2026-2050

- $11 \mathrm{~mm}$ year $^{-1}$ for 2051-2080

- $15 \mathrm{~mm} \mathrm{year}^{-1}$ for 2081-2115.

Guidance is also given for storm surges, where an assessment of extremes is recommended and upper-end estimates are provided as follows: $20 \mathrm{~cm}$ by the $2020 \mathrm{~s}$, $35 \mathrm{~cm}$ by the $2050 \mathrm{~s}$ and $70 \mathrm{~cm}$ by the 2080s. Work is underway on developing wave climate projections.

\subsubsection{Germany}

In Germany, the four federal states use three different methods for evaluating design water levels on the North Sea coast and adjacent estuaries. They have been tuned to yield similar values at the Cuxhaven gauge at the mouth of the Elbe estuary between 2010 and 2012. A matching value is achieved for the method practised in Schleswig-Holstein by adding an additional measure for the surge set-up in an estuarine mouth to the value achieved by the commonly used yearly exceedance probability of $5 \times 10^{-3}$. Hamburg has developed a new deterministic approach in order to meet the target range. Bremen and Lower Saxony met the anticipated target value beforehand by applying the traditionally used deterministic single-value method by combining the actual mean high water level with the highest values of maximum spring elevation, storm surge set-up and the chosen safety margin for climate change effects for the determination of design water levels. Design water levels in Lower Saxony and in the Netherlands at the Ems-Dollard estuary have similar values, the surge set-up of the design water level has a yearly exceedance probability of $2.5 \times 10^{-4}$. Tolerable wave overtopping at dykes is limited to $2\left[1 \times(\mathrm{m} \mathrm{s})^{-1}\right]$ in Schleswig-Holstein and to $3 \%$ in Bremen and Lower Saxony corresponding to an overtopping volume in the range of approximately $0.1-1.5\left[1 \times(\mathrm{m} \mathrm{s})^{-1}\right]$ with a tendency to correspond to the cross-sectional areas of dykes. All four states 
account for future climate change effects in the evaluation of design water levels by adding a general provision margin of $50 \mathrm{~cm}$ for 100 years. This measure would be equivalent to a SLR of about $40-45 \mathrm{~cm}$ per 100 years. Since 2012/2013 in Hamburg, $20 \mathrm{~cm}$ of the anticipated $50 \mathrm{~cm}$ SLR will be taken into account in the design of coastal protection structures with a lifespan to 2050. Whereas in Schleswig-Holstein and Hamburg the provision margin is a comprehensive part of the design water level, in Lower Saxony and Bremen a different approach is used in designing coastal structures: the provision margin is split into a SLR of $25 \mathrm{~cm}$ and an additional increase in storm surge set-up of $25 \mathrm{~cm}$. The latter requires higher storm velocities and so also takes into account higher wave energy. Furthermore, for the applied design procedure the - at least partial — adaption of tidal flats to an accelerated SLR is neglected leading to greater water depths and higher and longer waves in front of coastal structures. As a result, the incorporation of dynamic elements in the design procedure generates a higher safety margin than using an additional fixed value for design water levels. Furthermore, in Bremen, Hamburg and Lower Saxony, solid structures are constructed so as to accommodate an increase in water level beyond the anticipated safety margin; this comprises up to an additional $75 \mathrm{~cm}$ (Bremen), $80 \mathrm{~cm}$ (Hamburg) or $50 \mathrm{~cm}$ (Lower Saxony).

\subsubsection{Belgium}

The Flemish authorities are anticipating a SLR of about $6 \mathrm{~mm}$ year $^{-1}$ by 2050 and $10 \mathrm{~mm}$ year $^{-1}$ between 2050 and 2100 at the Belgian coast, and these values have been considered for planning and construction targeted at safety levels for 2050 and being ready by 2018 . The safety level is a yearly exceedance probability of $10^{-3}$ for both water level and waves, and is based on extreme value distributions for the determinative directions for very high storm surges. The design procedure is based on a storm duration of $45 \mathrm{~h}$, covering three tidal high peaks, for dunes, dykes, sluices, weirs and quay walls in harbours. The threshold of tolerable wave overtopping on dykes is $1\left[1 \times\left(\mathrm{m} \mathrm{s}^{-1}\right]\right.$ and dune erosion must be limited to a predefined level. Quay levels in harbours, heights of sluices and weirs will be checked with the aim of matching the design water levels. Risk analyses are carried out for four scenarios, including storm surges with higher tidal peaks than considered for the design storm surge up to a yearly exceedance probability of $5.89 \times 10^{-5}$. The aim is to derive basic information for the introduction of higher safety levels on the basis of a benefit-cost ratio and risk reduction if events occur for which evacuation is necessary. In the revised Sigma Plan for the Belgian part of the Western Scheldt estuary the design of coastal protection structures was based on a cost-benefit analysis (Broekx et al. 2011; Sigmaplan 2016).

\subsubsection{Netherlands}

To date, safety levels in the Netherlands refer to the recommendations of the first Delta Committee after the 1953 flood: a probabilistic flood safety definition based on the exceedance probabilities of water levels and waves. The safety levels differ between the various parts of the country in respect of population density, economic value and risk of flooding. Two safety levels have been established at the coast: $10^{-4}$ for the central Holland coast and $2.5 \times 10^{-4}$ year $^{-1}$ for the southwestern Delta area and the Wadden Sea with the Ems-Dollard estuary in the Northeast. Later overtopping tolerance on dykes has been limited to $0.1-1\left[1 \times\left(\mathrm{m} \mathrm{s}^{-1}\right]\right.$ depending on the quality of the cover layer. The Second Deltacommissie (2008) recommended raising safety standards ten-fold based on economic and population growth since 1953. Meanwhile, a decision has been made to replace the current procedure by a risk-based approach, incorporating the probability and degree to which a protection structure will fail if its design conditions are exceeded, as well as the loss of life and material damage that would occur in the event of a flood. A basic safety level is introduced, with a yearly probability of $10^{-5}$ as an upper limit for the loss of life due to flooding as local individual risk. For its evaluation two types of additional study are required: one on the threat to life due to flooding and one based on a societal cost-benefit-analysis. The final operational layout is expected to be introduced in 2016 in order to be ready for the safety assessment in 2017 (MIenM 2013). The Delta Commissioner expects that, to date, the safety levels used in coastal areas have led to protection structures that will meet the requirements of the new safety levels (Helpdesk Water 2015). Explorative studies of some dyke rings, however show that this new approach may lead to very different assessments of flood safety (Rijkswaterstaat 2005, 2015a). A more detailed investigation for the Lake IJssel area (Deltaprogramma IJsselmeergebied 2013) confirms this. The reason is that the failure of different stretches of dyke in a dyke ring may lead to different numbers of individuals being exposed to flooding. Safety margins for accelerated SLR due to the Delta scenarios range from 0.35 to $0.85 \mathrm{~m}$ until 2100 (Deltacommissaris 2013).

\subsubsection{Coastline Stabilisation and Anticipation of Morphological Changes}

Climate change will not only affect the hydrodynamic boundary conditions for coastal protection but will also cause morphological processes unfavourable to coastal protection. Knowledge about such developments and their consequences for coastal protection is much poorer than that 
available for future hydrodynamic loads. This lack of understanding about future morphological changes not only increases the uncertainties about future hydrodynamic loads but also includes the possibility that parts of the present coastal system could even disappear. A wide range of possible solutions are being considered in the coastal North Sea countries to tackle this problem, although the dimensions of morphological processes due to climate change impacts remain partly unknown. Solutions discussed in the following sections are all based on currently applied means to counter erosion.

\subsubsection{Germany}

In Germany, the Federal States of Bremen and Hamburg are responsible for relatively small sections of the open coast and have left the problem of morphological processes due to climate change impacts untouched in their adaptation scenarios to date. In the 'Masterplan Coastal Protection of the Federal State of Schleswig-Holstein' erosion due the BRUUN-rule is mentioned but only as a term without any consideration in respect of precautionary measures or as a topic for future research (MELUR 2013). Lower Saxony has developed an intensive research programme as part of the adaptation strategy, aiming to provide a robust evidence base for the planning of appropriate measures (MU 2012), but this programme has yet to start. In Schleswig-Holstein and in Lower Saxony structural erosion in sandy environments is typically compensated by artificial nourishments, particularly on barrier islands.

\subsubsection{Denmark}

Some parts of the sandy North Sea coast of Denmark experience structural erosion (Van de Graaff et al. 1991) which is compensated by artificial nourishments of 2-3 million $\mathrm{m}^{3}$ year ${ }^{-1}$. The total volume required is determined by the sum of:

- the annual average erosion above the $6 \mathrm{~m}$ depth contour between 1977 and 1996

- loss of nourished volume between the 6 and $10 \mathrm{~m}$ depth contour

- compensation for profile steepening since the middle of the period 1977-1996

- in the future, an extra $15 \%$ of the sum of all three to cover uncertainties.

Since artificial nourishment steepens the shoreface, extra volumes of material are likely to be needed to offset the effects of SLR. The Danish Coastal Authority has carried out intensive empirical studies to determine the volumes required for future nourishments to compensate for erosion due to accelerated SLR, shoreface steepening and increased longshore transport due to anticipated higher wave energy. The additional artificial supply for compensating for anticipated climate change effects under three scenarios averages $17 \%$ in 2050 and $49 \%$ in 2100 relative to the total volume of nourishment in 2008 (Jensen and Sørensen 2008).

\subsubsection{Belgium}

Structural erosion on the Flemish coast is counteracted by shoreface, beach and dune nourishments in order to reduce flood risk. The need for nourishment varies from section to section. Houthuys et al. (2012) noted a long-term general trend along the Flemish coast ranging from slight accretion in the west at the French border shifting to mild erosion east at the Dutch border. For the period 2013-2020, an average yearly volume of $20 \mathrm{~m}^{3} \mathrm{~m}^{-1}$ is considered necessary to meet the target safety level and provide a five-year buffer; which gives a total volume of 10 million $\mathrm{m}^{3}$. To address structural erosion and the projected SLR, an extra annual volume of $7 \mathrm{~m}^{3} \mathrm{~m}^{-1}$ corresponding to a total volume of 14 million $\mathrm{m}^{3}$ is expected to be needed between 2020 and 2050 (Balcaen 2012) of which about half is needed to compensate for SLR. This is based on the assumption of $500 \mathrm{~m}^{3} \mathrm{~m}^{-1}$ beach front for an average beach and a foreshore width of $500 \mathrm{~m}$.

\subsubsection{Netherlands}

Since the 1990s, the strategy for the sandy coasts of the Netherlands has been one of dynamic management to stabilise the basal coastline (Rijkswaterstaat 1990). This strategy was extended offshore beyond the shoreface to the $20 \mathrm{~m}$ depth contour in 2001, thus including the area known as the coastal foundation (Mulder et al. 2007). On average, 12 million $\mathrm{m}^{3}$ is used each year for nourishments along the sandy parts of the southwestern Delta, the closed Holland coast and on the West Frisian Barrier islands (Rijkswaterstaat 2011). Following the currently applied procedure (Mulder et al. 2007), increased demand for nourishments due to accelerated SLR and secondary effects will be identified by assessing the annual surveys every four years and then adjusting the amounts compensated within the following four years (Deltacommissaris 2013). However, the presently nourished volume is still insufficient to meet the aims (Mulder and Tonnon 2010): a total volume of 20 million $\mathrm{m}^{3}$ year $^{-1}$ is needed in relation to current SLR. The reason for this difference is largely due to the demand for sediments from the Western Scheldt estuary and the tidal basins of the Wadden Sea (de Ronde 2008). Although they are excluded from the nourishment programme these coastal areas benefit from sediment import from the coastal foundation. Recent studies on the adaption of the tidal basins of the Wadden Sea to the closure of the Zuider Zee and sand-mining, show that imported sediment volumes have been more than adequate to compensate for current SLR (Elias et al. 2012) which 
might indicate a sediment transport capacity through the inlets that is large enough to accommodate higher rates of SLR than currently occur. An increase in yearly nourishment volume to 20 million $\mathrm{m}^{3}$ is anticipated in the National Waterplan (MVenW 2009) but no decision has yet been made. The total amount of material to offset SLR is estimated to be proportional to the rate of SLR; 7 million $\mathrm{m}^{3}$ per $\mathrm{mm}$ year $^{-1}$. The Deltacommissie (2008) suggested that sediment budgets may need to increase to 85 million $\mathrm{m}^{3}$ year $^{-1}$ by 2050 , to compensate for a SLR of $12 \mathrm{~mm}_{\text {year }}{ }^{-1}$ along the whole Dutch coast including the southwestern Delta and the Wadden Sea, whereas the actually introduced scenarios for SLR assume rates of $3.5 \mathrm{~mm}$ year $^{-1}$ until 2050 and $8.5 \mathrm{~mm} \mathrm{year}^{-1}$ between 2050 and 2100 (Deltacommissaris 2013).

\subsubsection{United Kingdom}

With a coastline of about $18,000 \mathrm{~km}$, the United Kingdom is characterised by a wide range of shoreline types, inlets and estuaries. Historically, responses to coastal stabilisation were piecemeal and highly variable. Solutions included both hard constructions such as seawalls, breakwaters, groynes, and offshore reefs, and soft measures such as shingle recycling, beach nourishment and salt marsh generation. This local response has now been replaced by a more coherent and regional approach, through the adoption of Shoreline Management Plans to balance the requirements for safety against hazards and economic effort. The aim is to determine defence needs at a regional scale before defining the most appropriate form of protection to fulfil the strategic need. Central to this planning is a systematic and risk-based approach, underpinned by regional monitoring. Consideration is given to coastal geomorphology, geology, ecology, exposure, flood and erosion risk, protection type, and management strategy. Programme design focuses on the monitoring requirements needed to deliver new coastal engineering schemes over the next 30 years. Baseline surveys were undertaken for each survey category. Thereafter, a weighted sampling programme was developed according to identified risks, which determines the temporal and spatial frequency of data collection, reflecting factors such as the local geomorphology, exposure to wave climate and management strategy, to determine data requirements. Essentially, those areas that present high risk of erosion or flooding, or are heavily managed have more data collection than stretches of unmanaged coast. Hence, the entire UK coast is monitored at an appropriate level of detail to provide a strategic region-wide overview of coastal change. Consistent observation, specification, quality control, metadata and analysis techniques have been developed for each programme element. Web delivery includes online tools to view data and real-time observations of an extensive network of wave and tidal observations. In addition, a range of end-user products based on annual and cumulative analysis of the data enables coastal managers to develop a region-wide understanding of coastal evolution patterns (Channel Coastal Observatory 2013).

The shoreline management programmes will become more and more effective with an increasing data basis allowing more and more purposeful reactions of regional coastal managers in order to keep coastlines stable following the same basic criteria nationwide.

\subsection{Adaptation Strategies}

\subsubsection{Monitoring Climate Change Effects}

All coastal North Sea countries undertake coastal monitoring programmes to support the planning of construction and maintenance of coastal engineering schemes. Such programmes also provide a basis for scientific studies on process analysis, improving design procedures and verifying or driving models. Current monitoring programmes include a wide range of observation techniques including:

- terrestrial surveys by GPS and LIDAR of salt marshes, tidal flats, beaches and dunes or cliffs for moderate conditions, and the upper shoreface, beaches, dunes or cliffs for post-storm conditions

- bathymetric surveys of channels, shoreface and ebb deltas by GPS and sounding

- permanent water level monitoring by gauges

- permanent measurements of currents and salinity

- permanent wave monitoring by buoys or gauges

- monitoring of sediments and habitats.

Measuring campaigns are also undertaken to strengthen the data base for analysing and modelling hydrodynamic and morphodynamic coastal processes. Measurements are supplemented by model results covering hydrodynamic and morphodynamic processes and developments.

Although all North Sea coastal countries regard coastal monitoring as essential the approaches used vary widely, particularly in terms of spatial distribution and sampling frequency. Nevertheless, these data are still useful for detecting climate change impacts and developing coastal protection measures. However, it is important to keep the national monitoring programmes under review in respect of their suitability to deliver basic information for detecting climate change impacts relevant for coastal protection. The layout of monitoring programmes on coastal hydro- and morphodynamics is generally structured according to the knowledge about coastal processes as assembled in currently used coastal classifications like, for example, that of Hayes (1979) which consider tidal range and wave climate as 
driving forces but no varying SLR (Hayes and Fitzgerald 2013). It is therefore advisable to check whether the existing programmes are already sufficiently structured in respect of data mining and analysis for detecting effects of climate change impacts such as accelerated SLR, increased set-up of storm surges, growing wave energy and morphodynamic adaption.

A promising tool for identifying climate change impacts would be a combination of nationwide knowledge at least at the scale of the countries surrounding the North Sea. International interdisciplinary expert groups could then evaluate which data and information would be helpful in detecting climate change impacts in coastal areas as quickly and accurately as possible. The aim of these efforts should be standardised integrated monitoring around the North Sea supplemented by specific regional programmes addressing specific regional needs. The latter could also generate high quality data sets for driving and verifying mathematical models. Emphasis should also be given to improving and further developing analytical methods for evaluating monitoring data and model results with the aim of early detection of climate change impacts, especially trends. A parallel application of distinct analytical methods and forecast tools could provide comparable results; in case that similar results were found a sounder basis for decision-making could be achieved.

Since the scenarios for climate change impacts are still accompanied by large uncertainties due to the lack of basic knowledge needed for targeted cost-effective planning for coastal protection measures, any reduction in uncertainties by monitoring and the use of models implies a very good benefit-cost ratio.

\subsubsection{Belgium}

The Flemish authorities aim to keep the protection line at the Belgian North Sea coast. Improvements have taken place in the harbours that are currently considered the weakest links in the protection line and through which $95 \%$ of flooding is expected. In 2007-2008, work was undertaken to ensure a minimum safety level for a storm with a yearly exceedance probability of $10^{-2}$. Quay levels must be higher than the water level with an exceedance probability of $10^{-3}$ and the strength of dykes, sluices and weirs are checked. A storm surge barrier will be constructed in Nieuwpoort at the entrance to the Yser estuary and to the important yacht harbour of Nieuwpoort. Although this barrier will reduce the risk of flooding from the sea, it may also increase the risk of hinterland inundation due to reduced drainage capacity unless additional measures are taken.

Repeated nourishments include a safety margin for climate change effects. In addition, groynes are used to limit longshore transport. Possible positive effects of shoreface nourishments are debated and, for the longer term conceptual ideas of increasing the height of the existing Flemish Banks to reduce wave impact on shores are under consideration. Efforts are being made to limit aeolian transport, so keeping sediments where they can best help reduce hydrodynamic loads. The main design considerations are the use of a broad berm and a mild slope close to the equilibrium beach slope for the sand under consideration, with a preference for relatively coarse sand of about $300 \mu \mathrm{m}$ in diameter. High sand buffers in front of dykes with a minimum lifespan of five years are suggested.

In the Belgian part of the Western Scheldt an earlier study concluded that the cost of a storm surge barrier near Antwerp would not outweigh the benefits (Berlamont et al. 1982). This study did not include the possible effect of SLR and the Sigma Plan was recently revised: a combination of flood plains and heightening of dykes and quay walls is thought to provide the best solution in terms of costs for investment and maintenance and benefits such as preventing loss of agricultural production, as well as those from ecosystem services and the reduced probability of flooding in high-value areas (Broekx et al. 2011). This also means a change in strategy from a fixed safety level for the basin as a whole to a more flexible approach to safety in different parts of the basin.

\subsubsection{Denmark}

Protection of the hinterland against flooding at the Danish North Sea coast will continue to be achieved by keeping the protection line in its current position, with the exception of those areas where coastal retreat is regarded as acceptable and no human interference preventing it is deemed necessary. At the Danish Wadden Sea coast existing dykes are strengthened to meet prevailing safety levels and the anticipated safety margins for climate change effects are the measures used.

The protected stretch at the sandy North Sea coast of Denmark comprises those parts where the dunes are being armoured with concrete block revetments and those where the dunes are not. The minimum width for dunes with revetments is $30 \mathrm{~m}$ and for dunes without revetments $40 \mathrm{~m}$. These values were determined using erosion data from historical storm surges. Beach and shoreface erosion is currently compensated in front of dunes without revetments and due to a lack of funding is limited to a retreat of $3.2 \mathrm{~m}$ year $^{-1}$ in front of dunes with revetments, yielding narrower and lower beaches in front of the revetment. This is acceptable as long as the safety level for the revetments is not reduced beyond the safety threshold.

The adaptation strategy at the Danish North Sea coast has been developed on the basis of experience and understanding 
and aims less at fixed targets than at a flexible response to changing boundary conditions.

\subsubsection{Germany}

The Free and Hanseatic City of Hamburg generally employs the strategy of keeping the protection line in its current position. But very recently, some new infrastructure like large public buildings has been erected on dwelling mounds to prevent them flooding if dyke sections fail during a storm surge. The strategy in Schleswig Holstein for dykes at the mainland North Sea coast and on the North Frisian Islands is similar: in the current protection line dykes will be repeatedly strengthened relative to safety levels and safety margins. Since 2010, a new cross-sectional design has been applied enabling dykes to be raised up to $1.5 \mathrm{~m}$ for stronger hydrodynamic loads at some future date. The use of older dykes - those no longer in use due to the protection line after embankments moving seaward-is anticipated as a second protection line but is not yet implemented due to budget constraints. Tests on some sections showed the effectiveness of the second dyke line is often very limited. Nevertheless, it is considered worth preserving existing dykes in the second line as a basis for a new dyke line in the future. Information on design, dimensions and costs of strengthening dykes in the second line is lacking (MELUR 2013).

The Free and Hanseatic City of Bremen will keep the protection line in its current position. For its mainland coast and along the tidal estuaries Ems-Dollard, Weser and Elbe, Lower Saxony will do the same. This decision is the result of research on four alternative approaches. The investigations were undertaken in the Ems-Dollard estuary area which is representative of both estuaries and the Wadden Sea coast, with a stepwise increase in design water levels for a SLR of 0.65 and $1.00 \mathrm{~m}$ on the one hand, added to by an increase in storm-surge set-up of 0.35 and $0.5 \mathrm{~m}$ on the other (Niemeyer et al. 2014). The latter account for higher wind velocities on the one hand and higher and less attenuated wave energy on the other. Tidal flats were assumed not to adapt to accelerated SLR. This pessimistic scenario led to the following results:

- Retreat from all areas with flood risk due to storm surges in order to save on the cost of coastal protection. This implies that 1.2 million people in Lower Saxony would need to move to safe areas and about 800,000 people in neighbouring states would be at risk. However, cost savings versus economic losses mean that this strategy is out of the question, even for more pessimistic scenarios than those considered here.

- Accommodation by limiting coastal protection to settlements above a certain threshold of inhabitants and economic value. The costs of implementing the new coastal protection schemes are about $25 \%$ of the capital costs of the existing protection line if only the larger cities are safeguarded against storm surges and are of the same order of magnitude if all small villages are also protected. In addition, enormous efforts would be required to keep infrastructure between the protected areas such as railways, streets, energy supply lines operational after storm surge flooding. Even excluding other major disadvantages of this strategy, it is still clear that maintaining and strengthening the existing protection line is a better economic solution.

- Set-back or realignment leads to higher hydrodynamic loads than occur at the corresponding outer protection line, in all those areas where it has been moved seaward. Land levels in the areas sheltered by new dyke lines after reclamation have not been subject to sedimentation and are now lower than areas seaward of the dyke, particularly in saltmarshes. The greater water depths in front of the landward-shifted dykes by set-back allow higher wave energy. Without a gain in safety and with extra investment costs exceeding the current yearly budgets for coastal protection 120-fold for new dykes (MU 2012) this alternative is not better than the strategy of keeping the protection line in its current position.

- Combined protection with two structures; one for wave attenuation seaward and another to contain storm surge levels landward. Collectively these two structures would require a higher cross-sectional area than a single protection line. The safety achieved by such a scheme is less than that achieved by a conventional dyke and the costs would be significantly higher than for one dyke line.

The results show that strengthening the existing protection line is still the most effective solution both in terms of safety and cost (Niemeyer et al. 2011a, b, 2014). The government commission (MU 2012) and subsequently the State Government decided to follow the strategy of keeping the line in its current position and strengthening the protection structures. This approach was approved by the self-ruling dyke communities and through representative polls of people in the protected areas (MU 2012). To date, further studies have been undertaken for a SLR of $1.0 \mathrm{~m}$, an additional increase in storm surge set-up of $0.5 \mathrm{~m}$ and consistently higher and longer waves in the area of the Ems-Dollard estuary (Knaack et al. 2015). These studies led to the same conclusions as the previous studies: keeping the line is the optimal strategy for future protection of lowland coasts at the southern North Sea.

Successful site investigations on wave overtopping of dykes have been undertaken in Denmark (Laustrup et al. 1991), the Netherlands (van der Meer et al. 2009) and 
Vietnam (Le et al. 2013). They prove that higher overtopping volumes on dykes than are currently considered tolerable will be acceptable without failure of the structure. Wave overtopping on dykes has been modelled in combination with soil laboratory tests of the covering clay to develop an integrated design that takes into account both hydrodynamics and soil mechanics (Berkenbrink et al. 2010; Richwien et al. 2011). Several tests showed cover layers remained functional for overtopping volumes up to $200\left[1 \times(\mathrm{m} \mathrm{s})^{-1}\right]$. As overtopping volumes of this magnitude would probably cause severe damage in populated areas, acceptable overtopping volumes should be smaller. Studies were undertaken to quantify the extent to which an enhanced overtopping tolerance could counterbalance the effects of SLR or other climate change effects at three representative cross-sections for coastal and estuarine dykes in Lower Saxony. The results showed that an overtopping tolerance of $10\left[1 \times\left(\mathrm{m} \mathrm{s}^{-1}\right]\right.$ would allow a reduction in dyke crest heights for presently applied design conditions of 45-60 cm at the Lower Saxony North Sea coast and adjacent estuaries (Niemeyer et al. 2010). This suggests a survey of cover layers for all Lower Saxony coastal and estuarine dykes could help improve estimates of the design parameters for site-specific acceptable wave overtopping volumes, as part of the adaptation strategy for coastal protection (MU 2012). Such a survey would also identify weak points in the existing protection line.

Protection of the East Frisian Islands is currently undertaken using the same guidelines as in the past since the lack of understanding about climate change impacts on morphodynamic processes hampers the development of a resilient adaptation strategy (MU 2012).

\subsubsection{Netherlands}

The most recent decision on coastal protection strategy in the Netherlands is the adoption of a three-layer safety scheme combined with a new design procedure orientated at the probability of the loss of human life: prevention of flooding by keeping, strengthening and safeguarding the protection line remains the basis, which is extended with supporting measures to reduce the consequential damage of structural failure. The three-layer safety scheme is as follows:

- Layer 1: prevention of flooding by establishing and maintaining an effective flood protection system

- Layer 2: spatial planning such that the impact of flooding after the failure of protection structures is reduced

- Layer 3: disaster control through detailed evacuation plans, making sure that vital infrastructure is still functional in the event of a flood, and the creation of safe havens.
The self-governing waterboards ask for priority to be given to strengthening of the protection structures in order to meet prevailing safety norms, before investing in the second and third layer. The new system of risk-based safety norms differs from the current norm system based on hydrodynamic loads. The Cabinet adopted the new norm system in November 2014; its application is scheduled for 2017 and it is expected to take until 2050 for it to be implemented across the coastal protection system as a whole.

The costs of improving the structure of all existing dykes including those along inland waters, is estimated at about EUR 6.5 billion. An additional EUR 5 billion would be required for adaptation to a SLR of $0.5 \mathrm{~m}$. The sum of both is beyond the likely budget for the Delta Program for 2013 to 2028 (see Sect. 18.2.4). Conceptual studies on very safe dykes (Silva and van Velzen 2008) project an overtopping tolerance of $30\left[1 \times\left(\mathrm{m} \mathrm{s}^{-1}\right]\right.$ for coastal dykes.

The flood protection scheme for the Netherlands has a unique configuration: dyke rings surrounding protected areas. There are currently 54 dyke rings and the associated protection structures have a total length of $3767 \mathrm{~km}$, about $30 \%$ of these are at open tidal waters. Water Plan Beaufort is currently under development and is aimed at reducing the costs involved in improving protection structures to meet future safety levels, including those associated with climate change effects, as well as increasing options for setting priorities (Beaufort 2010/2013). A major element of the plan is a reduction in the number of dyke rings from 54 to 2 in line with the overall vision of shorter protection lines along sea and rivers and free outflow of rivers to the sea. Stronger dykes and extra locks and sluices are envisaged. Implementation may be phased, and efficient use of budgets should enable an increase in safety levels. Rough estimates indicate a cost saving of $50 \%$ compared to implementing the safety standards according to the Delta program. Water Plan Beaufort includes stronger dykes than at present and more thorough dyke inspections for detecting weak spots (Beaufort 2010/2013). The plan is still under development and not yet included in planning by the responsible Deltacommissaris (2013).

The strategy for keeping coastal dunes and protection structures safe and the coastal foundation stable by nourishments involves significant cost, although considered in terms of an insurance premium for protecting around EUR 1800 billion (Deltacommissie 2008) of invested capital in the protected area the costs seem relatively moderate and more reasonable. Nevertheless, attempts to make artificial nourishments more efficient, particularly by generating and applying knowledge of coastal processes, are still worthwhile.

An impressive example is the 'Delfland Sand Motor', a mega-nourishment with a volume of about 21.5 million $\mathrm{m}^{3}$ (Fig. 18.3) which is almost as big as the currently 


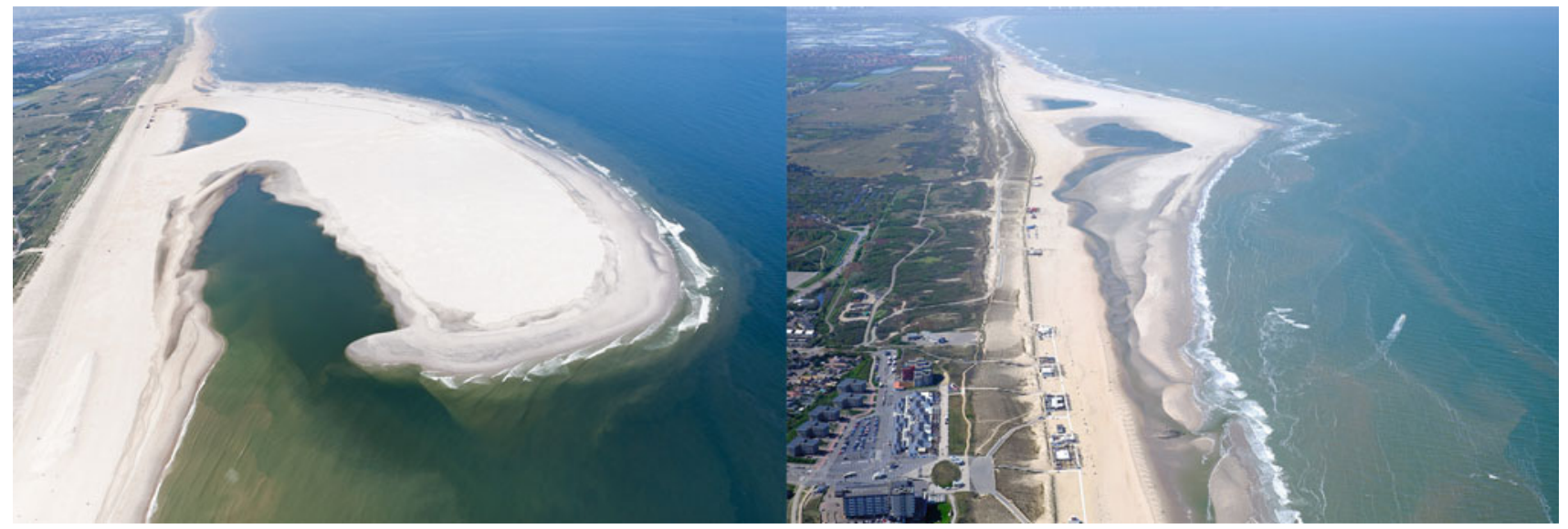

Fig. 18.3 Mega-nourishment 'Delfland Sand Motor'. After completion in July 2011 (left) and in May 2015 (right) after reshaping (https:// beeldbank.rws.nl, Rijkswaterstaat/Joop van Houdt)

implemented two-year volume of 24 million $\mathrm{m}^{3}$. Designing the sand motor required intensive testing by morphodynamic model predictions in order to optimise its shape and to compare its effectiveness with conventional nourishments for maintaining the coastal foundation of Delfland (Fig. 18.3). To keep pace with the present rate of SLR this requires about 5.5 million $\mathrm{m}^{3}$ within five years (Mulder and Tonnon 2010). Model results and measurements so far indicate that the Delfland Sand Motor will contribute to the maintenance of the coastal foundation of Delfland for around 25 years and that it is more cost-effective than repeated nourishments. But the model results also indicate that five additional nourishments will be necessary to maintain the coastline for this period. The alternatives for the shape of the sand motor have been shoreface nourishment, a bell-shape and a sandy hook (Mulder and Tonnon 2010). Because the coastal processes will rapidly transform any initial shape into a bell-shaped salient, the long-term morphological effects of the alternatives are similar. Combining the aim of the mega-nourishment to create long-term safety conditions as well as extra space for nature and recreation in an innovative manner, the environmental impact assessment showed the hook shape was preferable (Mulder and Tonnon 2010). The reshaping of the mega-nourishment is monitored and analysed. The results will improve the understanding of the effectiveness of this new type of artificial nourishment.

Another option tested recently is a seaward build-out of sandy coasts by over-nourishment, partly combined with supporting solid structures (Stronkhorst et al. 2010): coastal stretches receive excess amounts of sediment, creating beaches and dunes for nature conservation and recreation. Although the Deltacommissaris (2013) stated that this is a viable option, no specific decisions on this have yet been made.

\subsubsection{United Kingdom}

The approach to coastal protection in the United Kingdom focuses now on 'sedimentary cells' to reflect the adaptation needs of a regionally-varying coastline in terms of landscape, sedimentology and coastal dynamics. A distinction is made between coastal zone management (CZM) and so-called shoreline management. The former is predominantly a planning issue, seeking to reconcile the demands of development with the requirement for adequate protection of the natural environment. In contrast, shoreline management focuses on one aspect of CZM, namely coastal hazards, and concerns efforts to manage flood and erosion risk at the shoreline (Nicholls et al. 2013).

In the early 1990s, the government developed guidance for the preparation of 40 Shoreline Management Plans (SMPs) across England and Wales (MAFF 1995). The main objective was to define management units along the coast and consider the most appropriate Strategic Coastal Defence Options (SCDOs). The SCDOs considered for each management unit comprised four options for the strategy to be applied:

- do nothing

- maintain the existing protection line (while possibly adjusting the protection standard)

- advance the existing protection line

- retreat the existing protection line (subsequently referred to as 'managed realignment').

The management units were then used to initiate a consultation process and the compilation of each SMP, which, in some cases was adopted by the relevant authorities but this was and remains a non-statutory process. Outputs from the first round of SMPs were frequently biased towards the 
status quo - a fixed shoreline - which was at odds with the desire to move towards a more dynamic and adaptive coast, where appropriate. This led to a careful review of the process (Leafe et al. 1998) and new guidance was developed to promote the preparation of the second round of SMPs (DEFRA 2001). In this new guidance, greater emphasis was placed on:

- ensuring a more consistent evidence base was established

- the engagement of stakeholders throughout the process (but particularly in objective setting and selection of preferred options)

- adoption of the plans by the relevant authorities (DEFRA 2001).

Following a series of trials, this guidance was formally released (DEFRA 2006) and applied to England and Wales (DEFRA 2011). The second generation of SMPs are currently in production and when complete will cover the entire $6000 \mathrm{~km}$ shoreline. The intention is that the SMPs provide a 'route map' for local authorities and other decision makers to identify the most sustainable approaches to managing risks to the coast in the short term (0-20 years), medium term (20-50 years) and long term (50-100 years), recognising that changes to the present protection structures may need to be carried out as a staged process. Each SMP will include an action plan that prioritises works needed to manage specific flood and erosion risks, along with details of the coastal erosion monitoring and further research needed to support the plan. The SMPs then inform more detailed strategy studies, which explore the most effective form of delivery, with an increasing focus on adaptation measures that are more likely to be sustainable under a changing climate. For example, the long-term strategy for managing flood risk on the Thames Estuary, termed the Thames Estuary 2100 or TE2100 Project, includes options for managing flood risk to 2100 , based on current government projections of climate change. Each option comprises a sequence of interventions to 2100 and beyond and the assessment included consideration of the $\mathrm{H}++$, a low probability, high consequence scenario, which considers the possibility of large contributions to SLR from the Greenland and Antarctica ice sheets. The dates of implementation depend on the rate of climate change and other factors. If change such as rising sea level, or deterioration of the safety status of protection schemes occurs more rapidly than projected in the plan, intervention dates will be brought forward and vice versa. In this way, the timing of interventions on the estuary will be optimised, taking account of actual rates of change and associated updates of scientific knowledge and future projections. While this approach was developed specifically for London and the Thames Estuary, the concepts are now being adopted more widely (HM Treasury/DEFRA 2009).

\subsection{Summary and Recommendations}

This overview indicates that all countries around the North Sea with coastal areas vulnerable to flooding from storm surges are ready for the challenges that climate change is expected to bring. Scenarios have been developed and investigated as a basis for policy development, regulation and guidance, to provide a structured response that should ensure continued protection with the required level of safety for coastal flood prone areas.

Scenarios of accelerating SLR leading to changes in sea level of up to $1 \mathrm{~m}$ or more by 2100 have been used for planning the adaptation of coastal protection schemes. Thus the safety margins considered in all countries around the North Sea are consistent with the upper limit of SLR to 2100 reported in the latest assessment of the Intergovernmental Panel on Climate Change (IPCC 2013). There appears to be a tendency for countries with higher safety levels to consider smaller safety margins for climate change impacts than those with lower safety levels. Increased storm surge set-up and higher wave energy due to higher wind velocities are incorporated in the future design of coastal protection structures in Denmark, Bremen, Lower Saxony and the United Kingdom.

The United Kingdom has established a coastal protection strategy for a flexible response to erosion that reflects the varying conditions around the coast. The resulting strategy ranges from doing nothing or set-back of the protection line by managed realignment, to strengthening of the existing protection line. Denmark allows retreat at some stretches of its North Sea coast and maintains the protection line in the rest. All other countries aim at keeping the current protection line in place to protect the hinterland. In the Netherlands, a decision on implementing additional measures for reducing damage due to the failure of protection structures will be made in 2015. Investigations showed that a reliable basis for evaluating protection strategies is only achievable if real world tests are carried out, since conceptual studies can be misleading.

In all countries, artificial nourishments are traditionally used for combatting structural erosion on sandy coasts and this is expected to increase under future climate change impacts. This approach will thus be used more often and at higher rates for keeping the coastline in position according to the current criteria for intervention. The required increase in nourishment volumes needed to stabilise coastlines has been investigated in Belgium, Denmark and the Netherlands. In 
the Netherlands, models and large-scale site experiments have been used to gain deeper understanding of the relevant processes with the aim of increasing the efficiency of artificial nourishments or even moving the coastline seaward. In most countries, studies have been carried out to identify borrow areas with appropriate sediments and the volumes available. But there are still knowledge gaps concerning the long-term availability of sediments needed for nourishments to compensate for projected SLR, especially in terms of their being necessary to fulfil the needed volumes for nourishments in order to compensate the impacts of climate change in the long run, in particular in respect of the quality of sediments refilling the borrow pits and their suitability for future nourishments. A good understanding of the availability of suitable sediment reservoirs for nourishment is crucial for a sustainable management strategy to protect sandy coastal environments.

Climate change studies are based on scenarios rather than forecasts and this generates uncertainties, which by the end of a chain of processes may be unquantifiable. As a result, all North Sea countries use ongoing monitoring programmes for coastal management purposes. To help detect the impacts of climate change, some countries will even extend these monitoring programmes. The data provide a sound basis for detecting changes in trends. Testing existing tools and developing new analytical tools would be beneficial. Cooperation at a European scale would not only improve the exchange of knowledge, but would also improve the availability of tools, methodology and resources for problem solving.

Present knowledge already highlights that the effects of climate change at dynamic sandy coasts are stronger than on mainland coasts with cohesive sediments, such as estuaries or tidal basins with large intertidal areas and saltmarshes. Although the morphodynamic processes that are likely to occur due to climate change are reasonably well known, their quantification - if even possible - still involves large uncertainties. Filling the enormous knowledge gaps that still remain will be a challenge for coastal engineering in the future. Mitigating the morphodynamic changes due to climate change impacts will create high budget demands. For efficient measures it is necessary to understand and predict the hydrodynamic and morphodynamic changes that are likely to result from climate change. This justifies much higher budgets for research in this particular field than at present. Advancing process knowledge and improving long-term morphodynamic modelling are indispensable preconditions for providing decision-makers with a sound basis for target-orientated optimised measures. The knowledge potential in this field of expertise is extraordinarily good in Europe. The countries surrounding the North Sea would therefore benefit significantly from a co-ordinated programme aimed at reducing the knowledge gaps highlighted in this chapter.

Open Access This chapter is distributed under the terms of the Creative Commons Attribution 4.0 International License (http:// creativecommons.org/licenses/by/4.0/), which permits use, duplication, adaptation, distribution and reproduction in any medium or format, as long as you give appropriate credit to the original author(s) and the source, provide a link to the Creative Commons license and indicate if changes were made.

The images or other third party material in this chapter are included in the work's Creative Commons license, unless indicated otherwise in the credit line; if such material is not included in the work's Creative Commons license and the respective action is not permitted by statutory regulation, users will need to obtain permission from the license holder to duplicate, adapt or reproduce the material.

\section{References}

Afdeling Kust (2011) Masterplan Kustveiligheid. [Masterplan Coastal Safety] http://zeeweringenkustbeheer.afdelingkust.be/Userfiles/pdf/ 110628_RL_Rappor_\%20 KustveiligheidWEB4.pdf (In Dutch)

Balcaen N (2012) Masterplan Kustveiligheid [Masterplan Coastal Safety]. www.pianc-aipcn.be/figuren/verslagen\%20activiteiten\% 20Pianc\%20Belgi\%C3\%AB/Powerpoint/Kustveiligheid\% 20Nathalie\%20Balcaen\%2015feb2012.pdf (In Dutch)

Beaufort GA (2010/2013) Plan Beaufort, www.bureaubeaufort.com

Berlamont J, Sas M, Van Langenhove G, Thienpont M (1982) Multi-en interdisciplinaire evaluatiestudie betreffende de stormvloedkering te Antwerpen (Oosterweel) [Multi- and interdisciplinary evaluation study on a storm surge barrier at Antwerpen]. Report Hydraulics Laboratory KU Leuven (In Dutch)

Berkenbrink C, Kaiser R, Niemeyer HD (2010) Mathematical modelling of wave overtopping at complex structures: Validation and comparison In: McKee Smith J, Lynett P (eds), Proc 32nd Int Conf on Coastal Engineering, Shanghai, China. http://dx.doi.org/10. 9753/icce.v32.structures.4

Broekx S, Smets S, Liekens I, Bulckaen, D, De Nocker L (2011) Designing a long-term flood risk management plan for the Scheldt estuary using a risk-based approach. Nat Hazards 57:245-266

Bruun P (1962) Sea-level rise as a cause of shore erosion. Am Soc Civil Engineers Proc, J Waterw \& Harb Div 88:117-130

Channel Coastal Observatory (2013) Strategic regional coastal monitoring programmes of England, www.channelcoast.org

ComCoast (2007) ComCoast flood risk management schemes. www.ec. europa.eu/ourcoast/download.cfm?fileID=773

Danish Coastal Authority (2012) Guidelines for klimattilpasning I kystområder [Guidelines for climate change adaptation in coastal areas], www.masterpiece.dk/UploadetFiles/10852/36/ Klimatilpasningikystomr\%C3\%A5derversion2.pdf (In Danish)

Danish Government (2008) Danish Strategy for Adaptation to a Changing Climate. Danish Energy Agency

De Ronde J (2008) Toekomstige langjarige suppletiebehoefte. [Future long-term need for nourishments] Deltares Report Z4582.24, www. vliz.be/en/imis?module=ref\&refid=218721 (In Dutch)

DEFRA (2001) Shoreline Management Plans: A guide for coastal defence authorities. Department for Environment Food \& Rural Affairs (DEFRA), London

DEFRA (2006) Shoreline Management Plan Guidance. Vol 1: Aims and requirements, Vol 2: Procedures (plus 10 appendices). Department for Environment Food \& Rural Affairs (DEFRA), London 
DEFRA (2011) UK Climate Projections. www.ukclimateprojections. defra.gov.uk/09 Department for Environment Food \& Rural Affairs (DEFRA), London

DEFRA (2012) UK Climate Change Risk Assessment: Government Report, Department for Environment Food \& Rural Affairs (DEFRA), London www.gov.uk/government/publications/ukclimate-change-risk-assessment-government-report

Deltacommissaris (2013) www.deltacommissaris.nl/

Deltacommissie (2008) Working Together with Water: A living land builds for its future. Findings of the Deltacommissie 2008. www. deltacommissie.com/doc/deltareport_summary.pdf

Deltaprogramma Ijsselmeergebied (2013) Bijlage A3 Deltaprogramma 2014 [Supplement A3 Delta Programme 2014]. (In Dutch)

EEA (2012) Climate Change, Impacts and Vulnerability in Europe 2012. An indicator-based report. EEA Report No 12/2012. European Environment Agency (EEA)

Elias EPL, Van Der Spek AJF, Wang ZB, De Ronde J (2012) Morphodynamic development and sediment budget of the Dutch Wadden Sea over the last century. Neth J Geosci 91:293-310

Environment Agency (2013) Thames Estuary 2100 (TE2100) Plan. London

Hayes MO (1979) Barrier island morphology as a function of tidal and wave regime. In: Leatherman S (ed), Barrier Islands: From the Gulf of St. Lawrence to the Gulf of Mexico. Academic, pp 1-27

Hayes MO, Fitzgerald D (2013) Origin, evolution, and classification of tidal inlets. J Coast Res si 69:14-33

Helpdesk Water (2015) Kustveiligheid [Coastal Safety] www. helpdeskwater.nl/onderwerpen/water-en-ruimte/klimaat-0/ factsheets/kustveiligheid/ (In Dutch)

HM Treasury/DEFRA (2009) Accounting for the Effects of Climate Change: Supplementary Green Book Guidance. HM Treasury and Department for Environment Food \& Rural Affairs (DEFRA), London

Houthuys R, Mertens T, Geldhof A, Trouw K (2012) Long-term autonomous morphological trends of the Belgian shore. In: Belpaeme K, McMeel O, Vanagt T, Mees J (eds) 2012. Book of Abstracts. International Conference Littoral 2012: Coasts of Tomorrow, 27-29 November 2012, Oostende, Belgium. VLIZ Special Publication 61:191-193

IPCC (1990) Strategies for adaption to sea-level rise. Executive Summary of the Coastal Zone Management Subgroup. Intergovernmental Panel on Climate Change (IPCC), Response Strategies Working Group

IPCC (2013) Climate Change 2013: The Physical Science Basis. Contribution of Working Group I to the Fifth Assessment Report of the Intergovernmental Panel on Climate Change. Stocker, T.F., D. Qin, G.-K. Plattner, M. Tignor, S.K. Allen, J. Boschung, A. Nauels, Y. Xia, V. Bex and P.M. Midgley (eds.). Cambridge University Press.

Jensen J, Sørensen C (2008) Fremskrivning af fodringsindsatsen på Vestkysten [Projections of sand nourishment on the Danish west coast] Kystdirektoratet, Denmark (In Danish)

Kaiser R, Niemeyer HD (1999) Changing of local wave climate due to ebb delta migration. In: Edge BL (ed) Proc 26th Int Conf on Coastal Engineering, Copenhagen, Denmark

Knaack H, Berkenbrink C, Wurpts A, Kaiser R, Niemeyer HD (2015). Modellierung von Bemessungssturmfluten und Bemessungsseegang im Ems-Dollard-Ästuar für Klimaänderungsfolgen [Modeling of design storm surges and design waves due to climate change impacts]. Ber Forschungsstelle Küste 44:76-85 (In German)

Laustrup C, Toxvig Madsen H, Jensen J, Poulsen L (1991) Dike failure calculation model based on in situ tests. In: Edge BL (ed) Proc 22nd Int Conf on Coastal Engineering, The Hague, Netherlands. Part V: Coastal Processes and Sediment Transport, 2671-2681
Le HT, Van Der Meer J, Quang Luong N, Verhagen HJ, Schiereck GJ (2013) Wave overtopping resistance of grassed dike slopes in Vietnam. Coastal Structures 2011:191-202

Leafe R, Pethick J, Townend IH (1998) Realizing the benefits of shoreline management. Geogr J 164:282-290

Lowe JA, Howard TP, Pardaens A, Tinker J, Holt J, Wakelin S, Milne G, Leake J, Wolf J, Horsburgh K, Reeder T, Jenkins G, Ridley J, Dye S., Bradley S (2009) UK Climate Projections Science Report: Marine and coastal projections. Met Office Hadley Centre, Exeter

MAFF (1995) Shoreline Management Plans: A guide for coastal defence authorities. Ministry of Agriculture Fisheries and Food (MAFF), London

MELUR (2013) Generalplan Küstenschutz des Landes Schleswig-Holstein [Masterplan Coastal Protection of the Federal State of SchleswigHolstein]. Ministerium für Energiewende, Landwirtschaft, Umwelt und ländliche Räume des Landes Schleswig-Holstein. www.schleswigholstein.de/DE/Fachinhalte/K/kuestenschutz/Downloads/Generalplan. pdf;jsessionid=59F186586AAC9A3C825EF3AF0D4754BA?_blob= publicationFile \&v=1 (In German)

MIenM (2013) Koersbepaling waterbeleid en toezeggingen WGO van 10 december 2012 [Letter of the Minister for Infrastructure and Environment to the Second Chamber of the Dutch Parliament]. www.rijksoverheid.nl/documenten-en-publicaties/kamerstukken/ 2013/04/26/koersbepaling-waterbeleid-en-toezeggingen-wgo-van10-december-2012.html (In Dutch)

MU (2012) Empfehlungen für eine niedersächsische Strategie zur Anpassung an die Folgen des Klimawandels [Recommendations for an Adaption Strategy for Climate Change Effects in Lower Saxony]. www.umwelt.niedersachsen.de/klimaschutz/aktuelles/107128.html (In German)

Mulder JPM, de Vos FJ (1989) Kustverdedigung na 1990 - inventarisatie functies onderwateroever [Coastal Protection after 1990: Inventory of shoreface functions]. Rijkswaterstaat. Rep No 9 (In Dutch)

Mulder JPM, Tonnon PK (2010) 'Sand engine': Background and design of a mega-nourishment pilot in the Netherlands. In: McKee Smith J, Lynett P (eds), Proc 32nd Int Conf on Coastal Engineering, Shanghai, China. http://dx.doi.org/10.9753/icce.v32.management.35

Mulder JPM, Nederbragt G, Steetzel HJ, Van Koningsveld M, Wang ZB (2007) Different implementation scenarios for the large scale coastal policy of the Netherlands. In: McKee Smith J (ed) Proc 30th Int Conf on Coastal Engineering, San Diego, California

Müller JM, Zitman T, Stive MJF, Niemeyer HD 2007. Long-term morphological evolution of the tidal inlet 'Norderneyer Seegat', In: McKee Smith J (ed) Proc 30th Int Conf on Coastal Engineering, San Diego, California

MVenW (2009) Nationaal Waterplan [National Waterplan] 2009-2015. www.rijksoverheid.nl/documenten-en-publicaties/rapporten/2009/ 12/01/nationaal-waterplan-2009-2015.html (In Dutch)

Nicholls RJ, Townend IH, Bradbury AP, Ramsbottom D, Day SA (2013) Planning for long-term coastal change: experiences from England \& Wales. Ocean Eng 71:3-16

Niemeyer HD (1983) Über den Seegang an einer inselgeschützten Wattküste [On waves at an island-sheltered Wadden Sea coast]. BMFT-Forschungsber. MF 0203 (In German)

Niemeyer HD (2005) Coastal protection of lowlands: Are alternative strategies purposeful for changing climate? In: Proceedings of the 14th Biennial Coastal Zone Conference, New Orleans, Louisiana

Niemeyer HD (2010) Protection of coastal lowlands: Are alternative strategies a match to effects of climate change? In: Proc 17th IAHR-APD Conference, Auckland, New Zealand

Niemeyer HD (2015) Effekte des Klimawandels auf Randbedingungen im Insel- und Küstenschutz -gegenwärtige und $\mathrm{zu}$ erwartende Trends- [Effects of climate change on boundary conditions for coastal protection - current and expected trends]. Ber Forschungsstelle Küste 44:1-55 (In German) 
Niemeyer HD, Kaiser R (2001) Design wave evaluation for coastal protection structures in the Wadden Sea. In: Edge BL, Hemsley JM (eds) Ocean Wave Measurement and Analysis, Vol. II

Niemeyer HD, Kaiser R, Berkenbrink C (2010) Increased overtopping security of dykes: a potential for compensating future impacts of climate change. In: McKee Smith J, Lynett P (eds), Proc 32nd Int Conf on Coastal Engineering, Shanghai, China. http://dx.doi.org/10. 9753/icce.v32.structures.11

Niemeyer HD, Kaiser R, Knaack H, Dissanayake P, Miani M, Elsebach J, Berkenbrink C, Herrling G, Ritzmann A (2011a) Evaluation of coastal protection strategies for lowlands in respect of climate change. In: Valentine EM, Apelt CJ, Ball J, Chanson H, Cox R, Ettema R, Kuczera G, Lambert M, Melville BW, Sargison JE (eds) Proc 34th World Congress Int Assoc Hydro-Environm Res \& Eng, Australia

Niemeyer HD, Berkenbrink C, Miani M, Ritzmann A, Dissanayake P, Knaack H, Wurpts A, Kaiser R (2011b) Coastal protection of lowlands: are alternative strategies a match to effects of climate change. In: Schüttrumpf $\mathrm{H}$, Tomassicchio GR (eds) Proc 5th Int Short Conf Appl Coast Res, Aachen, Germany

Niemeyer HD, Berkenbrink C, Ritzmann A, Knaack H, Wurpts A, Kaiser R (2014) Evaluation of coastal protection strategies in respect of climate change impacts. Die Küste 81:565-578

Ranasinghe R, Duong TM, Uhlenbrook S, Roelvink D, Stive MJF (2012) Climate-change impact assessment for inlet-interrupted coastlines. Nature Clim Change 3:83-87

Richwien W, Pohl C, Vavrina L (2011) Bemessung von Deichen gegen Einwirkungen aus Sturmfluten [Dyke design in dependence of loads during storm surges]. Die Küste 77:1-44 (In German)

Rijkswaterstaat (1989) Kustverdiging na 1990 - discussienota [Coastal Protection after 1990 - discussion]. (In Dutch)

Rijkswaterstaat (1990) A new coastal defence policy for the Netherlands. Public Works Department, Tidal Waters Division

Rijkswaterstaat (2005) Veiligheid Nederland in Kaart. Hoofdrapport onderzoek overstromingsrisico's [The Netherlands on maps, Report on the risk of flooding]. DWW 2005-81 (In Dutch)

Rijkswaterstaat (2011) Suppletieprogramma: 2012-2015 [Nourishment programme 2012-2015] http://slideplayer.nl/slide/2837415/

Rijkswaterstaat (2015a) Dijkringrapporten [Dyke Ring Reports]. www. helpdeskwater.n1/onderwerpen/waterveiligheid/programma'-projecten/ veiligheid-nederland/publicaties/dijkringrapporten/ (In Dutch)

Rijkswaterstaat (2015b) Kwaliteit Waterkeringen [Quality of flood protection structures]. http://www.rijkswaterstaat.nl/water/waterbeheer/ bescherming-tegen-het-water/kwaliteit-waterkeringen/index.aspx (in Dutch)

Schuerch M, Vafeidis A, Slawig T, Temmerman S (2013) Modeling the influence of changing storm patterns on the ability of a salt marsh to keep pace with sea-level rise. J Geophys Res 118:84-96

Senat FHH (2012) Hochwasserschutz für Hamburg [Flood Protection in the City of Hamburg]. Mitteilung des Senats an die Bürgerschaft-Drucksache 20/5561, www.landtag.nrw.de/portal/WWW/ dokumentenarchiv/Dokument/GGD20-5561.pdf (In German)
Sigmaplan (2016) The Sigma Plan www.sigmaplan.be/en

Silva W, van Velzen E (2008) De dijk van de toekomst? [Dyke for the Future?]. Deltares Report No RWS 2008.052, www.rijksoverheid. nl/documenten-en-publicaties/rapporten/2008/10/01/de-dijk-van-detoekomst-quick-scan-doorbraakvrije-dijken.html (In Dutch)

Stive MJF, de Vriend HJ (1995) Modelling shoreface profile evolution. Mar Geol 126:235-248

Stive MJF, Eysink W (1989) Dynamisch model van het Nederlandse kustsystem [Dynamical model of the Dutch coastal system]. WL Delft Hydraul Rep M 825-IV (In Dutch)

Stronkhorst J, Van Rijn L, De Vroeg H, De Graaff R, Van Der Valk B, Van Der Spek A, Mulder JPM, Oost A, Luijendijk A, Oude Essink G (2010) Technische mogelijkheden voor een dynamische kustuitbreiding. [Technical possibilities of seaward extensions of coastlines] Deltares 1201993-004-VEB-0002, www.rijksoverheid.nl/binaries/rijksoverheid/ documenten/rapporten/2010/07/29/technische-mogelijkheden-vooreen-dynamische-kustuitbreiding-een-voorverkenning-t-b-v-hetdeltaprogramma/technische-mogelijkheden-voor-een-dynamischekustuitbreidingbieb.pdf (In Dutch)

STW (2013) Publicatie in Nature voor nieuwe manier van kustverdediging met schorren en kwelders [Publication in 'Nature' on a New Approach in Coastal Protection by Shallows and Salt Marshes]. www.stw.nl/en/node/6502 (In Dutch)

SUBV (2012) Klimawandel in Bremen - Folgen und Anpassung. [Climate change in Bremen - impacts and adaptation] www. bauumwelt.bremen.de/sixcms/media.php/13/BdV_L_S_ Klimaanpassung\%20Anlage_Endf.pdf (In German)

Temmerman S, Meire P, Bouma TJ, Peter MJ, Herman PMJ, Ysebaert T, De Vriend HJ (2013) Ecosystem-based coastal defence in the face of global change. Nature 504:79-83

Townend IH, Fletcher C, Knappen M, Rossington K (2011) A review of salt marsh dynamics. Water Environ J 25:477-488

Van De Graaff J, Niemeyer HD, Van Overeem, J (1991) Beach nourishment, philosophy and coastal protection policy. Coast Eng 16:3-22

Van Der Meer JW, Steendam GJ, De Raat G, Bernardini P (2009) Further developments on the wave overtopping simulator. In: McKee Smith J (ed) Proc 31st Int Conf on Coastal Engineering, Hamburg, Germany

Vlaamse Baaien (2015a) Flanders Bays 2100. www.vlaamsebaaien. com/flanders-bays-2100

Vlaamse Baaien (2015b) http://www.maritiemetoegang.be/vlaamsebaaien

Weisse R, von Storch H, Niemeyer HD, Knaack H (2012) Changing North Sea storm surge climate: an increasing hazard? Ocean Coast Manage 68:58-68

Woth K, Weisse R, von Storch H (2006) Climate change and North Sea storm surge extremes: ensemble study of storm surge extremes expected in a changed climate projected by four different regional climate models. Ocean Dynam 56:3-15 